\title{
Natural contents of metals in soils from basaltic origins in western Paraná, Brazil
}

\author{
Cleidimar João Cassol'® ${ }^{1}$, Adelmo Lowe Pletsch²®, Ismael Laurindo Costa Júnior ${ }^{3} \oplus$,

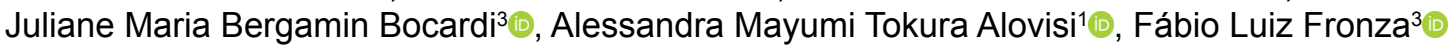

\footnotetext{
1 Universidade Federal da Grande Dourados, Dourados, MS, Brasil. E-mail: cleidimar_cassol@hotmail.com; alessandraalovisi@ufgd.edi.br

2 Universidade Tecnológica Federal do Paraná, Santa Helena, PR, Brasil. E-mail: adelmo@utfpr.edu.br

33 Universidade Tecnológica Federal do Paraná, Medianeira, PR, Brasil. E-mail: isma_jr@hotmail.com; julianebocardi@gmail.com; fabio_fronza@hotmail.com
}

ABSTRACT: This study aimed to determine the natural content of environmentally available metals $(\mathrm{Cd}, \mathrm{Cr}, \mathrm{Pb}, \mathrm{Cu}, \mathrm{Fe}, \mathrm{Mn}$ and $\mathrm{Zn}$ ) in soils from basaltic origin (Oxisols, Ultisols, Entisols and Alfisols) in western Paraná. The metal ions were extracted with a $0.1 \mathrm{~mol} \mathrm{~L}^{-1} \mathrm{HCl}$ acid solution and quantified by atomic absorption spectrophotometry. The highest Cu concentration $(0.68 \mathrm{mg}$ $\left.\mathrm{dm}^{-3}\right)$ was found in Oxisol, while the Ultisol had the highest $\mathrm{Zn}$ content $\left(16.4 \mathrm{mg} \mathrm{dm}^{-3}\right)$. The highest Fe and $\mathrm{Mn}$ contents were found in Oxisol $\left(5.04 \mathrm{mg} \mathrm{dm}^{-3}\right)$. The highest Mn content, in turn, was in the Ultisol (463.4 $\mathrm{mg} \mathrm{dm}^{-3}$ ). Principal component analysis showed an association between $\mathrm{Zn}$ and $\mathrm{Mn}$, and between $\mathrm{Cu}$ and clay. The data presented in this study can be used as a content reference for the environmentally available metal for similar soils and for environmental monitoring programs, since they are soils from preserved areas.

Key words: metals; principal component analysis; soils

\section{Teores naturais de metais em solos de origem basáltica do Oeste do Paraná, Brasil}

RESUMO: Objetivou-se com esse estudo determinar o teor natural de metais ambientalmente disponíveis ( $\mathrm{Cd}, \mathrm{Cr}, \mathrm{Pb}, \mathrm{Cu}, \mathrm{Fe}$, Mn e Zn), em solos de origem basáltica Latossolo Vermelho, Nitossolo Vermelho, Neossolo Regolítico, e Gleissolo Háplico, na região Oeste do Paraná. Os íons metálicos foram extraídos com solução ácida de $\mathrm{HCl} 0,1 \mathrm{~mol} \mathrm{~L}^{-1}$, e quantificados por espectrofotometria de absorção atômica. A maior concentração de $\mathrm{Cu}\left(0,68 \mathrm{mg} \mathrm{dm}^{-3}\right)$ foi encontrada no Latossolo Vermelho, enquanto o Nitossolo Vermelho apresentou o maior teor de Zn $\left(16,4 \mathrm{mg} \mathrm{dm}^{-3}\right)$. O maior teor de Fe foi encontrado no Latossolo Vermelho $\left(5,04 \mathrm{mg} \mathrm{dm}^{-3}\right)$. $O$ maior teor de $\mathrm{Mn}$, por sua vez, no Nitossolo Vermelho $\left(463,4 \mathrm{mg} \mathrm{dm}^{-3}\right)$. Por meio da análise de componentes principais verificou-se associação entre os metais $\mathrm{Zn}$ e $\mathrm{Mn}$, e Cu e argila. Os dados apresentados nessa pesquisa poderão ser usados como referência dos teores de metais ambientalmente disponíveis para solos semelhantes e para programas de monitoramento ambiental, uma vez que são solos de áreas preservadas.

Palavras-chave: metais; análise de componentes principais; solos 


\section{Introduction}

The soil is one of the environmental compartments of utmost importance for the living beings, as it provides several essential conditions such as the climate regulation, nutrient cycling, food production, among others (FAO, 2015). However, in recent decades, this resource has undergone several changes in its natural characteristics due to the increasing activities intended for food production, which increasingly demand the use of chemical and organic inputs (Cassol et al., 2018).

Considering the need in preventing soil contamination, the Brazilian National Environment Council (CONAMA) issued the Resolution No. 420/2009, amended by Resolution No. 460/2013, which provides criteria and guiding values for soil quality regarding the presence of chemical substances, establishing guidelines for environmental management of areas contaminated by these due to the anthropogenic activities (Brazil, 2009).

The quality guiding values are nothing more than the determination of potentially toxic elements or substances in soils with no direct anthropogenic contribution, which serve as criteria for comparison with soils of similar characteristics. To that end, several Brazilian states have already established their own quality guiding values, including Rio Grande do Sul more recently (Althaus et al., 2018); Minas Gerais (Guevara et al., 2018); Amazonas (Souza et al., 2018) and western Paraná (Bocardi, 2019).

Despite the recognized advancement that Resolution $420 / 2009$ brought about, there still is the important gap of determining the natural contents of environmentally available metals in the short and medium term, which are estimated by more dilute acid solutions such as $0.1 \mathrm{~mol} \mathrm{~L}^{-1} \mathrm{HCl}$ (Andrade et al., 2009). It is noteworthy that the methodologies recommended by Resolution 420/2009 for the QRV generation are considered as pseudo-totals such as 3050 or 3051 from the United States Environmental Protection Agency (USEPA) and its updates (Brazil, 2009). These methodologies use more concentrated extraction solutions such as (USEPA 3051A concentrated $\mathrm{HNO}_{3}$ and $\mathrm{HCl}$ at 3:1 (v/v)) and (USEPA 3050B - $\mathrm{HNO}_{3}+\mathrm{H}_{2} \mathrm{O}_{2}$ ) (Santos \& Alleoni, 2013).

Acid solutions that are more dilute, according to Andrade et al. (2009), are used for estimating the non-exchangeable contents and the heavy metals availability in the short/ medium term. Thereby, the objective of this study was to determine the natural contents of the metals cadmium (Cd), chromium $(\mathrm{Cr})$, copper $(\mathrm{Cu})$, iron $(\mathrm{Fe})$, manganese $(\mathrm{Mn})$, lead $(\mathrm{Pb})$ and zinc $(\mathrm{Zn})$ in soils with absence or minimal anthropogenic contribution, in the western region of Paraná. It was also to evaluate possible interactions between metals and physical and chemical parameters, by means of the principal components analysis (PCA).

\section{Materials and Methods}

The study area is located in western Paraná, a region that has several forest remnants, with the Iguaçu National Park standing out as the largest remnant of Atlantic forest in the state, and other conservation units types such as Private Natural Heritage Reserve (RPPN ) and Legal Reserve (RL). These conservation units altogether enabled the collection of soil from preserved native forest environments.

Figure $1 \mathrm{~A}$ illustrates the map of forest remnants, while $1 \mathrm{~B}$ has the pedological map. In order to create the vegetation map, the used images were provided by the non-governmental organization (NGO) SOS Mata Atlântica, while the pedological map was made by using the cartographic base provided by the Institute of Land, Cartography and Geosciences (ITCG, 2019). The software used to create both maps mentioned was the Qgis version 2.14.5 .

Twenty-six points were sampled and the following four soil classes were identified: Oxisol (O), Ultisol (U), Entisol (E) and Alfisol (A) (Respectively Latossolo Vermelho, Nitossolo Vermelho, Neossolo Regolítico and Gleissolo Háplico , according to Embrapa, 2013). Table 1 displays the geographic coordinates, geology, environmental units, municipalities and soil types of the sampled points. Geographic coordinates were obtained by using the GPS from the brand Garmin Trex Legend ${ }^{\circ}$.

The collections were throughout 2016, and followed handling, preservation, packaging and transportation

A.

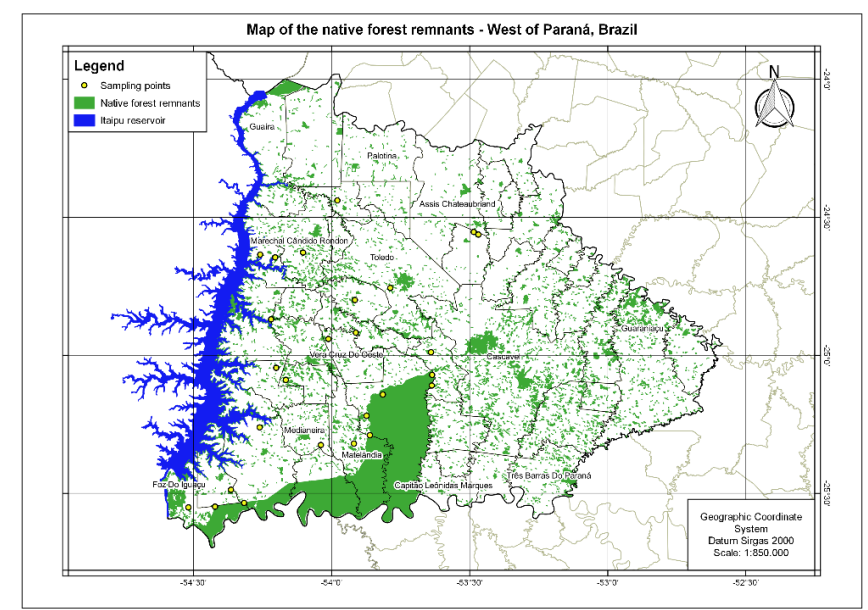

B.

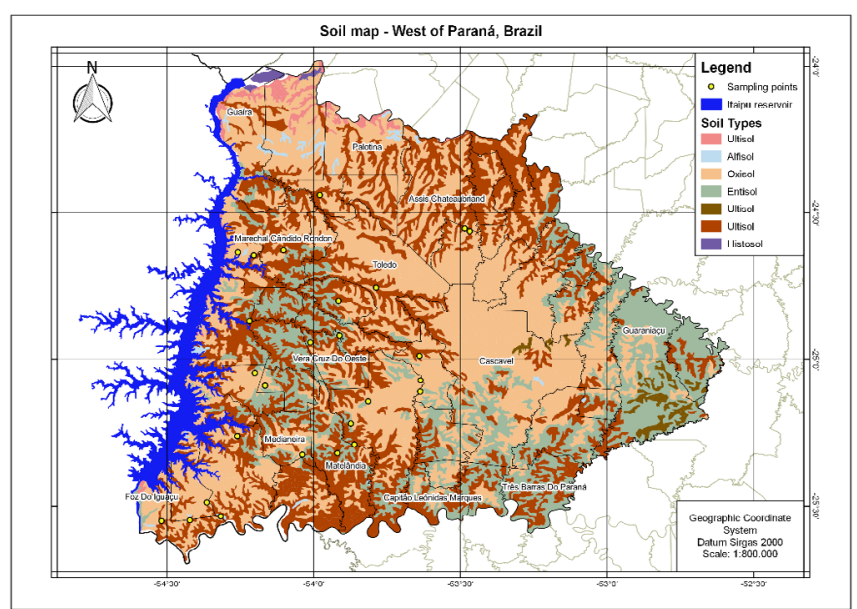

Figure 1. Maps of the forest remnants $(A)$ and the soils $(B)$ of western Paraná. 
Table 1. Sampling points, geographical coordinates, geology, environmental units, municipalities and soil types.

\begin{tabular}{|c|c|c|c|c|c|c|}
\hline Points & $\begin{array}{c}\text { Geographical } \\
\text { S }\end{array}$ & $\begin{array}{c}\text { Coordinates } \\
\text { W }\end{array}$ & $\begin{array}{c}\text { Geological formation/ } \\
\text { Rock Type* }\end{array}$ & $\begin{array}{c}\text { Environmental } \\
\text { unit }\end{array}$ & Municipality & Soils** \\
\hline 1 & $24^{\circ} 50^{\prime} 55.38^{\prime \prime}$ & $54^{\circ} 20^{\prime} 35.99^{\prime \prime}$ & Serra Geral/Basalt & $\mathrm{RL}$ & $\mathrm{SH}$ & Oxisol \\
\hline 2 & $24^{\circ} 41^{\prime} 4.46^{\prime \prime}$ & $53^{\circ} 45^{\prime} 11.70^{\prime \prime}$ & Serra Geral/Basalt & RPPN & $\mathrm{T}$ & Oxisol \\
\hline 3 & $24^{\circ} 13^{\prime} 36.63^{\prime \prime}$ & $54^{\circ} 11^{\prime} 3.97^{\prime \prime}$ & Serra Geral/Basalt & RPPN & N.S.R & Oxisol \\
\hline 4 & $24^{\circ} 33^{\prime} 11.08^{\prime \prime}$ & $53^{\circ} 29^{\prime} 6.96^{\prime \prime}$ & Serra Geral/Basalt & $\mathrm{RL}$ & TU & Oxisol \\
\hline 5 & $25^{\circ} 13^{\prime} 9.26^{\prime \prime}$ & $53^{\circ} 52^{\prime} 24.58^{\prime \prime}$ & Serra Geral/Basalt & PARNA & C.A & Oxisol \\
\hline 6 & $25^{\circ} 6^{\prime} 34.54^{\prime \prime}$ & $53^{\circ} 38^{\prime} 13.36^{\prime \prime}$ & Serra Geral/Basalt & PARNA & S.T.O & Oxisol \\
\hline 7 & $25^{\circ} 19^{\prime} 30.80^{\prime \prime}$ & $54^{\circ} 2^{\prime} 19.76^{\prime \prime}$ & Serra Geral/Basalt & RPPN & ME & Oxisol \\
\hline 8 & $24^{\circ} 50^{\prime} 57.26^{\prime \prime}$ & $53^{\circ} 40^{\prime} 9.82^{\prime \prime}$ & Serra Geral/Basalt & RE & S.T.O & Ultisol \\
\hline 9 & $24^{\circ} 37^{\prime} 26.37^{\prime \prime}$ & $53^{\circ} 57^{\prime} 22.12^{\prime \prime}$ & Serra Geral/Basalt & RL & Q.P & Ultisol \\
\hline 10 & $24^{\circ} 37^{\prime} 40.01^{\prime \prime}$ & $54^{\circ} 6^{\prime} 11.79^{\prime \prime}$ & Serra Geral/Basalt & $\mathrm{RL}$ & M.C.R & Ultisol \\
\hline 11 & $25^{\circ} 19^{\prime} 12.12^{\prime \prime}$ & $53^{\circ} 55^{\prime} 9.23^{\prime \prime}$ & Serra Geral/Basalt & RL & MA & Ultisol \\
\hline 12 & $25^{\circ} 16^{\prime} 57.50^{\prime \prime}$ & $54^{\circ} 6^{\prime} 15.37^{\prime \prime}$ & Serra Geral/Basalt & $\mathrm{RL}$ & ME & Ultisol \\
\hline 13 & $25^{\circ} 19^{\prime} 13.60^{\prime \prime}$ & $53^{\circ} 55^{\prime} 8.63^{\prime \prime}$ & Serra Geral/Basalt & PARNA & MA & Ultisol \\
\hline 14 & $25^{\circ} 30^{\prime} 11.90^{\prime \prime}$ & $54^{\circ} 12^{\prime} 13.68^{\prime \prime}$ & Serra Geral/Basalt & PARNA & S.M.I & Ultisol \\
\hline 15 & $25^{\circ} 32^{\prime} 39.66^{\prime \prime}$ & $54^{\circ} 22^{\prime} 23.24^{\prime \prime}$ & Serra Geral/Basalt & PARNA & S.T.I & Ultisol \\
\hline 16 & $24^{\circ} 45^{\prime} 54.74^{\prime \prime}$ & $54^{\circ} 17^{\prime} 27.49^{\prime \prime}$ & Serra Geral/Basalt & $R L$ & $\mathrm{SH}$ & Entisol \\
\hline 17 & $25^{\circ} 4^{\prime} 13.95^{\prime \prime}$ & $54^{\circ} 4^{\prime} 5.46^{\prime \prime}$ & Serra Geral/Basalt & $\mathrm{RL}$ & $\mathrm{R}$ & Entisol \\
\hline 18 & $24^{\circ} 44^{\prime} 6.82^{\prime \prime}$ & $54^{\circ} 3^{\prime} 8.04^{\prime \prime}$ & Serra Geral/Basalt & $\mathrm{RL}$ & M.C.R & Entisol \\
\hline 19 & $25^{\circ} 15^{\prime} 34.91^{\prime \prime}$ & $53^{\circ} 59^{\prime} 27.24^{\prime \prime}$ & Serra Geral/Basalt & $\mathrm{RL}$ & $\mathrm{MA}$ & Entisol \\
\hline 20 & $25^{\circ} 9^{\prime} 13.25^{\prime \prime}$ & $53^{\circ} 47^{\prime} 52.12^{\prime \prime}$ & Serra Geral/Basalt & PARNA & C.A & Entisol \\
\hline 21 & $25^{\circ} 20^{\prime} 24.66^{\prime \prime}$ & $53^{\circ} 22^{\prime} 8.46^{\prime \prime}$ & Serra Geral/Basalt & PARNA & S.T.O & Entisol \\
\hline 22 & $24^{\circ} 56^{\prime} 12.80^{\prime \prime}$ & $54^{\circ} 1^{\prime} 52.82^{\prime \prime}$ & Serra Geral/Basalt & $\mathrm{RL}$ & V.C.O & Entisol \\
\hline 23 & $24^{\circ} 55^{\prime} 5.20^{\prime \prime}$ & $53^{\circ} 54^{\prime} 44.24^{\prime \prime}$ & Serra Geral/Basalt & RB & S.P.I & Entisol \\
\hline 24 & $24^{\circ} 44^{\prime} 55.22^{\prime \prime}$ & $54^{\circ} 12^{\prime} 16.62^{\prime \prime}$ & Serra Geral/Basalt & $\mathrm{RL}$ & E.R.O & Alfisol \\
\hline 25 & $25^{\circ} 5^{\prime} 24.88^{\prime \prime}$ & $54^{\circ} 11^{\prime} 55.40^{\prime \prime}$ & Serra Geral/Basalt & $\mathrm{RL}$ & $\mathrm{MI}$ & Alfisol \\
\hline 26 & $25^{\circ} 32^{\prime} 54.95^{\prime \prime}$ & $54^{\circ} 25^{\prime} 19.78^{\prime \prime}$ & Serra Geral/Basalt & PARNA & S.T.I & Alfisol \\
\hline
\end{tabular}

Environmental Unit $-\mathrm{RL}=$ Legal Reserve; RE = Ecological Retreat; RPPN = Private Natural Heritage Reserve; PARNA = National Park; RB = Biological Reserve; Municipality - S. H = Santa Helena; C.VEL = Cascavel; V.C.O = Vera Cruz do Oeste; $\mathrm{R}=$ Ramilândia; $\mathrm{T}=$ Toledo; Q.P = Quatro Pontes; E.R.O = Entre Rios do Oeste; M.C.R = Marechal Candido Rondon; S.T.O = Santa Tereza do Oeste; S.P.I = São Pedro do Iguaçu; TU = Tupãssi; MA = Matelândia; ME = Medianeira; MI = Missal; N.S.R = Nova Santa Rosa; S.M.I = São Miguel do Iguaçu; C.A = Céu Azul; S.T.I = Santa Teresinha de Itaipu. *(ITCG, 2019); **(Embrapa, 2013).

procedures all in accordance with the national and international standards, respecting the validity periods, as well as regional characteristics (Brazil, 2009).

For acquiring the samples, five equidistant points were perforated two meters apart in each soil. Subsequently, using a small hoe and a stainless steel shovel, five sub-samples were taken from the 0 to $20 \mathrm{~cm}$ depth, which after homogenization, composed a composite sample (Bocardi et al., 2018).

To perform the analytical determinations, the samples went first through air-drying and homogenization in a $2 \mathrm{~mm}$ stainless steel sieve. The granulometric analysis (texture) was performed by the densimeter method, based on sedimentation of the constituent particles from the soil (Embrapa, 1997). The granulometric variables had the following values: clay - 623, 568, 397 and $306 \mathrm{~g} \mathrm{~kg}^{-1}$, for OS, US, ES and AS soils, respectively; sand - 313, 211, 202 and $175 \mathrm{~g} \mathrm{~kg}^{-1}$, for ES, US, AS and OS soils, respectively; and silt - 491, 289, 219 and $200 \mathrm{~g} \mathrm{~kg}^{-1}$, for AS, ES, US and OS soils, respectively.

Chemical attributes such as hydrogen potential $(\mathrm{pH})$ in $\mathrm{CaCl}_{2}$; organic carbon $(\mathrm{CO})$, potassium $\left(\mathrm{K}^{+}\right)$, sodium $\left(\mathrm{Na}^{+}\right)$, calcium $\left(\mathrm{Ca}^{2+}\right)$, magnesium $\left(\mathrm{Mg}^{2+}\right)$, exchangeable aluminum $\left(\mathrm{Al}^{3+}\right)$, potential acidity $(\mathrm{H}+\mathrm{Al})$ and phosphorus $(\mathrm{P})$ were all determined according to the Manual of Soil Analysis Methods (Embrapa, 1997). From the obtained results, the cation exchange capacity (CEC) at $\mathrm{pH} 7$, percentages of base saturation (V\%) and the sum of bases (SB) were calculated. All physical and chemical attributes are illustrated in Table 2.

In order to quantify the natural contents of $\mathrm{Cd}, \mathrm{Pb}, \mathrm{Cu}, \mathrm{Cr}$, $\mathrm{Fe}, \mathrm{Mn}$ and $\mathrm{Zn}$ metals, the acid extraction of the soil samples was employed with $0.1 \mathrm{~mol} \mathrm{~L}^{-1} \mathrm{HCl}$ (Tedesco, 1995; CQFS-RS/ SC, 2016). Determination of the metal ions was performed in a Flame Atomic Absorption Spectrophotometer, (FAAS, Variam - AA-220 spectra). Its calibration was performed by using standard solutions of the studied metal ions, through linear range for each analyte. Absorbance measurements were taken in the area integration mode.

The method was validated by analyzing the linearity, the regression of the calibration curves of each metal and determining the limits of quantification (LQ) and detection (LD), with these calculated from the analytical curve parameters.

Results obtained were evaluated by descriptive statistical analysis means. In order to verify similarities and differences between variables and soil classes, the Principal Component Analysis (PCA) was applied. All statistical analysis were performed using the Statistica 10.0 software.

\section{Results and Discussion}

The metals $\mathrm{Cd}, \mathrm{Cr}$ and $\mathrm{Pb}$ had values below the detection limit of the analytical method, which in turn may be related 
Table 2. Descriptive statistics of the physical and chemical parameters from studied soils.

\begin{tabular}{|c|c|c|c|c|c|c|c|c|c|c|c|c|c|}
\hline \multirow{2}{*}{ Soils } & & \multirow{2}{*}{$\mathrm{pH}$} & $\mathrm{H}+\mathrm{Al}$ & $\mathrm{Al}^{3+}$ & $\mathrm{Ca}^{2+}$ & $\mathrm{Mg}^{2+}$ & SB & CEC & \multirow{2}{*}{$\begin{array}{l}V \\
\text { (\%) }\end{array}$} & $\mathrm{K}^{+}$ & $\mathrm{Na}^{+}$ & \multirow{2}{*}{$\begin{array}{c}P \\
\left(\mathrm{mg} \mathrm{kg}^{-1}\right)\end{array}$} & \multirow{2}{*}{$\begin{array}{c}O C \\
\left(g^{-1} g^{-1}\right)\end{array}$} \\
\hline & & & \multicolumn{6}{|c|}{$\left(\mathrm{cmol}_{\mathrm{c}} \mathrm{dm}^{3}\right)$} & & \multicolumn{2}{|c|}{$\left(\mathrm{cmol}_{\mathrm{c}} \mathrm{dm}^{3}\right)$} & & \\
\hline \multirow{4}{*}{ OS } & Mea. & 5.03 & 6.57 & 0.18 & 3.72 & 1.84 & 5.91 & 12.4 & 48 & 0.35 & 0.02 & 2.99 & 20.2 \\
\hline & Min. & 3.61 & 2.72 & 0.03 & 0.15 & 0.19 & 0.38 & 8.58 & 2.87 & 0.03 & 0.01 & 0.30 & 5.43 \\
\hline & Max. & 5.64 & 13.1 & 0.98 & 7.1 & 2.7 & 10.4 & 14.9 & 71.3 & 0.77 & 0.02 & 5.29 & 28.3 \\
\hline & $s$ & 0.7 & 3.4 & 0.35 & 2.5 & 1 & 3.2 & 2.22 & 23.8 & 0.28 & 0.00 & 1.61 & 1.22 \\
\hline \multirow{2}{*}{ US } & Mea. & 5.54 & 5.38 & 0.05 & 7.59 & 4.31 & 12.2 & 17.6 & 65.2 & 0.39 & 0.07 & 5.59 & 24.2 \\
\hline & $s$ & 0.45 & 1.88 & 0.03 & 4.26 & 2.55 & 6.54 & 5.66 & 19.8 & 0.33 & 0.07 & 7.86 & 1.52 \\
\hline \multirow{4}{*}{ ES } & Mea. & 5.37 & 6.21 & 0.03 & 8.93 & 3.72 & 13 & 19.2 & 64 & 0.38 & 0.04 & 8.53 & 30.5 \\
\hline & Min. & 4.36 & 3.46 & 0.01 & 2.40 & 2.13 & 5.25 & 13.3 & 28.8 & 0.08 & 0.01 & 1.38 & 4.94 \\
\hline & Max. & 6.13 & 12.9 & 0.06 & 18.4 & 5.70 & 24.4 & 27.9 & 87.5 & 0.78 & 0.12 & 42.6 & 35.9 \\
\hline & $\mathrm{s}$ & 0.56 & 3.10 & 0.01 & 6.15 & 1.36 & 7.50 & 5.87 & 21.1 & 0.22 & 0.04 & 13.9 & 2.32 \\
\hline AS & Mea. & 4.76 & 9.68 & 0.35 & 0.93 & 0.69 & 1.77 & 11.4 & 17.2 & 0.15 & 0.09 & 3.05 & 27.8 \\
\hline
\end{tabular}

$\mathrm{OS}=$ Oxisol; US = Ultisol; $\mathrm{ES}=$ Entisol; $\mathrm{AS}=$ Alfisol; Mea. = Mean; Min. = minimum; Max. = maximum; $\mathrm{s}=$ standard deviation; $\mathrm{CEC}=$ cation exchange capacity $(\mathrm{SB}+\mathrm{H}+\mathrm{Al}$ ); $\mathrm{SB}=$ sum of bases $\left(\mathrm{Ca}^{2+}, \mathrm{Mg}^{2+}, \mathrm{K}^{+}\right) ; \mathrm{V}=$ base saturation $(\mathrm{SB} / \mathrm{CEC}) \times 100 ; \mathrm{OC}=$ organic carbon.

to the lower occurrence of these elements in nature, allied with the acidic and moderately acidic soil conditions. When in these, the mobility of said elements and their losses by leaching can be decisive for their low content in the soil (Paye et al., 2010). LD values for $\mathrm{Cd}, \mathrm{Cr}$ and $\mathrm{Pb}$ were respectively $0.02 ; 0.17 ; 1.06 \mathrm{mg} \mathrm{dm}^{-3}$.

The highest mean Mn content found was in US, of $463.4 \mathrm{mg}$ $\mathrm{dm}^{-3}$, followed by ES and OS, with mean values of 390.2 and $337.4 \mathrm{mg} \mathrm{dm}^{-3}$, respectively (Table 3 ). The lowest Mn content found was in AS $112.4 \mathrm{mg} \mathrm{dm}^{-3}$, which may be associated with the high $\mathrm{Mn}$ mobility in reduced environments (KabataPendias, 2011). Mn abundance in the soils is associated with the presence of mafic rocks in the region lithology, having basalt in its formation. This condition allows greater concentration and upkeep of $\mathrm{Mn}$ in the soil system. Table 3

Table 3. Descriptive statistics of the metal contents for the studied soils.

\begin{tabular}{|c|c|c|c|c|c|}
\hline \multirow{2}{*}{ Soils } & & Mn & $\mathrm{Fe}$ & $\mathrm{Cu}$ & $\mathrm{Zn}$ \\
\hline & & \multicolumn{4}{|c|}{$\left(\mathrm{mg} \mathrm{kg}^{-1}\right)$} \\
\hline \multirow{4}{*}{ OS } & Med. & 337.4 & 5.04 & 0.68 & 9.32 \\
\hline & Min. & 66.4 & 1.78 & 0.05 & 0.71 \\
\hline & Max. & 586 & 8.98 & 1.99 & 21 \\
\hline & $\mathrm{s}$ & 201 & 3.02 & 0.71 & 8.4 \\
\hline \multirow{4}{*}{ US } & Med. & 463.4 & 3.65 & 0.60 & 16.4 \\
\hline & Min. & 235 & 1.18 & 0.15 & 4.39 \\
\hline & Max. & 640 & 7.07 & 1.94 & 33 \\
\hline & $\mathrm{s}$ & 123 & 2.08 & 0.62 & 11 \\
\hline \multirow{4}{*}{ ES } & Med. & 390.2 & 1.81 & 0.41 & 7.50 \\
\hline & Min. & 151 & 0.84 & 0.11 & 3.70 \\
\hline & Max. & 567 & 3.83 & 2.06 & 11.7 \\
\hline & $\mathrm{s}$ & 133 & 1.11 & 0.66 & 2.78 \\
\hline \multirow{4}{*}{ AS } & Med. & 112.4 & 2.70 & 0.15 & 1.92 \\
\hline & Min. & 47.6 & 1.76 & 0.15 & 0.03 \\
\hline & Max. & 209 & 4.31 & 0.15 & 3.45 \\
\hline & $s$ & 85.5 & 1.40 & 0.01 & 1.74 \\
\hline LD & & 0.009 & 0.65 & 0.14 & 0.02 \\
\hline
\end{tabular}

OS = Oxisol; US = Ultisol; ES = Entisol; AS = Alfisol. Med. = mean; Min. = minimum; Max. $=$ maximum; $s=$ standard deviation; $L D=$ detection limit. also displays the amplitude of $\mathrm{Mn}$ content in the soils, with values sitting between 47.6 and $640 \mathrm{mg} \mathrm{dm}^{-3}$.

$\mathrm{Mn}$ content in soils are dependent on the $\mathrm{pH}$ and the oxireduction potential. These considerations can also extend to $\mathrm{Fe}$, due to the similarities between these two elements. This may explain the lack of guiding values regarding these metals in the soils defined by environmental agencies (Biondi et al., 2011).

The highest observed Fe contents were in the OS and US soils, compared to the other ones analyzed, averaging contents 5.04 and $3.65 \mathrm{mg} \mathrm{dm}^{-3}$, respectively. These soils have undergone more intense pedogenetic processes.

During the pedogenetic processes, there is greater removal of silt and bases from the soil profile, resulting in a predominance of $\mathrm{Fe}$ and $\mathrm{Al}$ oxide minerals and 1:1 silicates such as the kaolinite in the mineralogical composition of the soil clay fraction (Ribas, 2010). However, the content found in soils are much lower than the reported by other researchers, when analyzing soils associated with mafic and ultramafic rocks (Burak, 2008; Caires, 2009).

The highest found $\mathrm{Cu}$ concentration was in the OS $(0.68 \mathrm{mg}$ $\left.\mathrm{dm}^{-3}\right)$, while the US had the highest $Z n$ content $\left(16.4 \mathrm{mg} \mathrm{dm}^{-3}\right)$. All soils had high $\mathrm{Zn}$ concentrations, with the same occurring for $\mathrm{Cu}$, except for the AS, which classified as low content $(0.15$ $\mathrm{mg} \mathrm{dm}^{-3}$ ) (CQFS-RS/SC, 2016).

A study conducted in Rio Grande do Sul, analyzing soils originated from five different source materials, observed higher $\mathrm{Cu}$ and $\mathrm{Zn}$ contents in soils derived from basalt (Althaus et al., 2018). These types of soils have higher concentrations of $\mathrm{Cu}$ and $\mathrm{Zn}$ when compared to others from different lithologies (Hugen et al., 2013).

\section{Principal component analysis}

Principal component analysis (PCA) allowed to verify that the first two main components (CP 1 and 2) explained $94.02 \%$ of the data variance, with $69.85 \%$ from CP 1 and $24.17 \%$ 
from CP 2, (Figure 2A and 2B). Based on the correlations, the variables that best explained the data variance are $\mathrm{Al}^{3+}, \mathrm{Ca}^{2+}$, $\mathrm{Cu}, \mathrm{K}^{+}, \mathrm{Mg}^{2+}, \mathrm{Mn}, \mathrm{Zn}, \mathrm{OC}, \mathrm{pH}$, Silt, SB, H+Al, CEC and V\% CP 1, and Fe, P, Sand and Clay CP 2.

Figure $2 \mathrm{~A}$ illustrates the high correlations between the variables $\mathrm{pH}, \mathrm{Mg}^{2+}, \mathrm{SB}$ and third quadrant $\mathrm{Ca}^{2+}$, because, as according to Hongyu et al. (2016), the smaller the angles formed in relation to the abscissa axis are, the higher the correlations between the variables will be.

The variables $\mathrm{OC}, \mathrm{K}^{+}, \mathrm{Mn}$, and $\mathrm{Zn}$ in the second quadrant showed high correlations, possibly due to the soil organic

A.

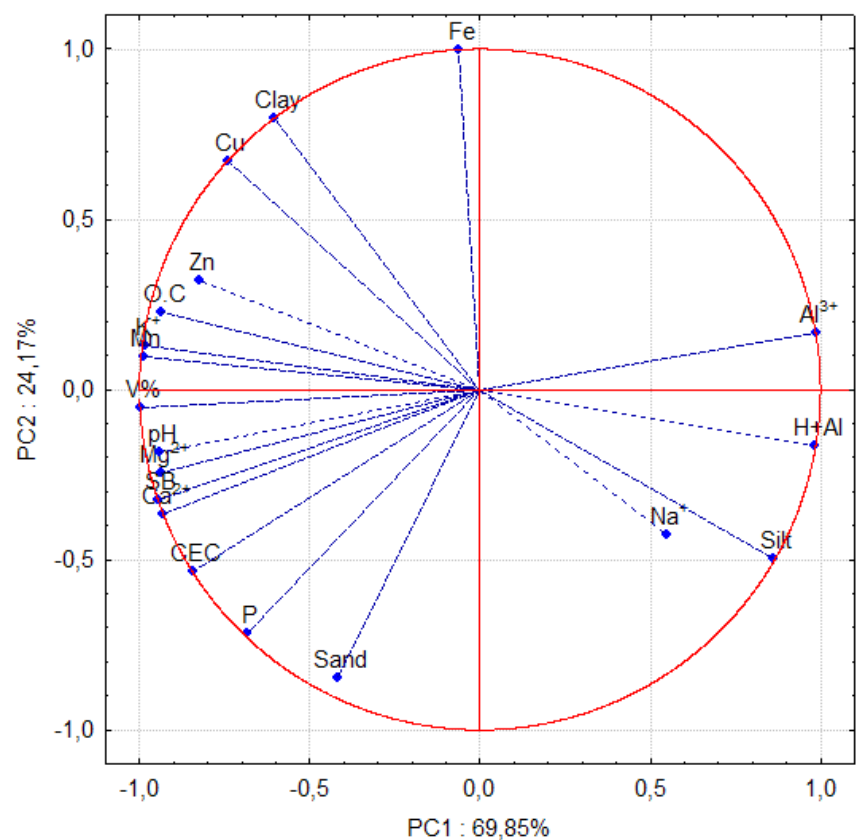

B.

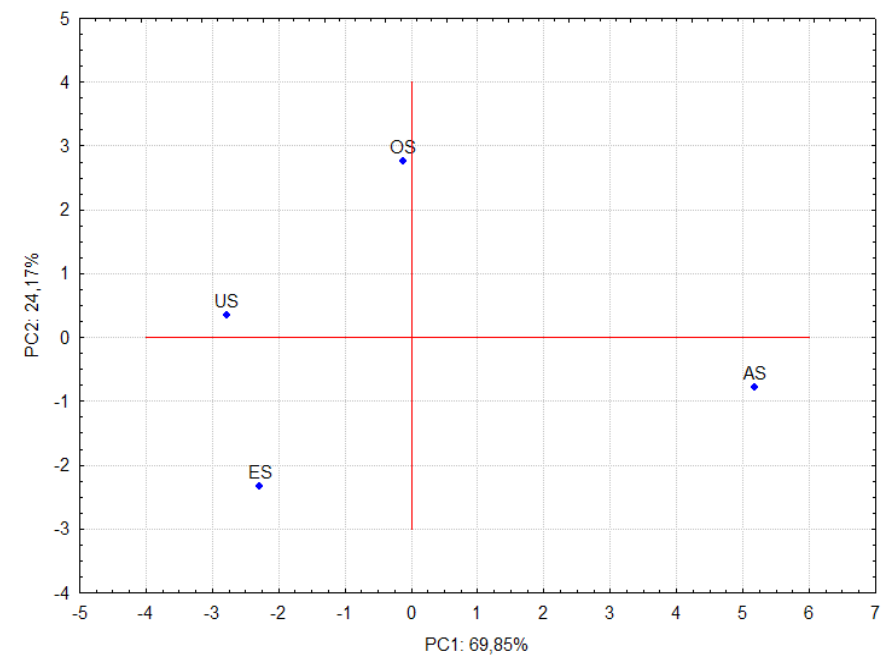

Figure 2. Principal component analysis with the eigenvector circle from 19 variables and 26 samples of surface horizons from the Oxisol, Ultisol, Entisol and Alfisol soils (A). Principal component analysis illustrating the cluster formed by soil classes as a function of their variables (B). OS = Oxisol; US = Ultisol; $E S=$ Entisol; $A S=$ Alfisol; $O C=$ organic carbon, $C E C$ = cation exchange capacity at $\mathrm{pH} \mathrm{7,} \mathrm{V} \%$ = base saturation in percentage, $\mathrm{SB}=$ sum of bases, $\mathrm{H}+\mathrm{Al}=$ potential acidity matter capacity in retaining cations and metallic elements such as Mn and $\mathrm{Zn}$ (Cordovil et al., 2014).

The association of clay with second quadrant $\mathrm{Cu}$ (Figure 2A) can be explained by the strong $\mathrm{Cu}$ adsorption on the surface of the clay fraction colloids, indicating that a large part of this element is concentrated in clay minerals and the Fe oxides that compose this fraction (Biondi et al., 2011).

Strong correlations suggest similar geochemical behavior in soils from the same source material (Althaus et al., 2018). Freitas et al. (2014) analyzed Oxisols under three different uses, and by means of principal component analysis found a strong correlation between $\mathrm{Ca}, \mathrm{Mg}$ and $\mathrm{pH}$ in an environment cultivated with sugarcane; while in a reforested area the correlations were between $\mathrm{B}, \mathrm{Cu}$ and $\mathrm{Zn}$; and in native forest they were $\mathrm{OM}, \mathrm{Fe}, \mathrm{Al}$ and $\mathrm{H}+\mathrm{Al}$.

The soil classes grouping (Figure $2 \mathrm{~B}$ ) reflects the individual contribution of each variable for defining each component. The closer a soil class is to another, the greater the similarity of its characteristics are. Thus, from the studied soil classes, OS and US were verified as positioned in the second quadrant, in which the OS was located closer to the Y-axis and the US closer to the X-axis. The ES positioned in the third quadrant and $A S$ in the fourth quadrant (Figure $2 B$ ).

The main variables responsible for the OS cluster are clay, $\mathrm{Fe}$ and $\mathrm{Cu}$, which were in higher contents in comparison with the other studied soils. The angles formed by these variables are smaller in comparison with the one that formed by OC, which is an important variable in Cu retention. This, in turn, suggests that the clay fraction is the main source from Fe and $\mathrm{Cu}$ in the $\mathrm{O}$.

A similar study found that sandier soils have less metal retention capacity when compared to clayier soils (Oliveira et al., 2010). This is observed in the present study, where the concentrations from the metallic elements $\mathrm{Fe}, \mathrm{Cu}, \mathrm{Zn}$ and $\mathrm{Mn}$ were higher in the OS and US, both clayier than the other studied soils.

Another important factor to be taken into account on the availability of metallic elements for soil solution is the $\mathrm{pH}$, (Melo et al., 2008), since it was verified a reduction in the available contents of $\mathrm{Cd}, \mathrm{Pb}, \mathrm{Cu}$ and $\mathrm{Zn}$ in the soil with an increase in $\mathrm{pH}$ due to liming. Organic matter acts in the formation of complexes with metallic elements, decreasing their availability and toxicity to plants (Santos \& Rodella, 2007).

For the cluster formed by US, the metallic elements $\mathrm{Zn}$ and Mn stand out for forming acute angles with the organic matter, indicating it has a high capacity for retaining these elements in this case, possibly in function of processes such as adsorption and complexation. There is a high selectivity degree of humic substances by certain metals, which is why some metallic elements have a greater affinity with $\mathrm{OC}$ in relation to others, with this said affinity reflecting the correlations between metallic elements and OC (Kyziol et al., 2006; Campos, 2010).

In the cluster formed by the third quadrant ES, the high correlation between the variables $\mathrm{Mg}, \mathrm{Ca}, \mathrm{SB}$ and $\mathrm{pH}$ are in evidence due to their formation of acute angles. In relation 
to the metallic elements $\mathrm{Fe}, \mathrm{Cu}, \mathrm{Zn}$ and $\mathrm{Mn}$, the observed was that they are in lower concentrations in ES when compared to the OS and US, possibly due to the ES having a higher sand content and less pedogenetic development. Other variables that interfere with the availability of $\mathrm{Fe}, \mathrm{Cu}, \mathrm{Zn}$ and $\mathrm{Mn}$ in the soil are the organic matter and the $\mathrm{pH}$; however, the values found for these were alike.

Source material is yet another factor that influences the concentrations of metallic elements in the soil; however, all soils are from the same formation source, but with a different development stage. Soils like OS, highly weathered, are generally rich in iron and aluminum oxides, a characteristic that favors the retention of metallic elements such as $\mathrm{Fe}, \mathrm{Cu}$, $\mathrm{Zn}$ and $\mathrm{Mn}$, as it the observed in this study.

On the other hand, the ESs are poorly developed soils that have more characteristics from their original material. They are soils with little expression of the pedogenetic processes performance, insufficient to cause significant changes in the original material due to their weathering resistance, which is inherent to the actual original material itself, in addition to the climate, which, in an individual manner or in a joint action, prevents or limits these soils evolution (Santos et al., 2012).

The cluster formed in the fourth quadrant AS highlights $\mathrm{Na}$, silt, $\mathrm{H}+\mathrm{Al}$ and $\mathrm{Al}$ as the main variables that distinguished this soil from the other ones studied. The silt content in AS reflects the recent sedimentary nature of the mineral particles constituting the soil in this environment, evidencing a lower pedogenetic development degree (Guimarães et al., 2013). The exchangeable Al content may be resulting from the ferrolysis process, generally found in soils subject to periodic waterlogging, or due to the acidic $\mathrm{pH}$ of 4.7 found in this soil (Coringa et al., 2012).

The content of $\mathrm{Na}$ can be explained by it being an ion with high solubility, when compared to $\mathrm{Ca}, \mathrm{Mg}$ and $\mathrm{K}$, and thus it is more likely to migrate with drainage waters from the hydrographic basin to the lower relief areas, resulting in its higher concentrations in lowland soils such as the AS. In this context, the conclusion is that some characteristics, such as the formation process, hydromorphic character and relief position, are exclusive to AS in relation to the other studied soils, and that these characteristics mainly reflected on the silt, $\mathrm{Na}, \mathrm{Al}$ and $\mathrm{H}+\mathrm{Al}$ variables.

PCA proved to be an important tool in evaluating the relation between the variables, and in separating soil classes as well, which also belong to the same source material, but with different development stages.

The data contained in this research can be used as reference in the content of available metals for similar soils exposed to anthropogenic action and to environmental monitoring programs, since these soils are from extremely preserved areas.

\section{Conclusion}

The metals $\mathrm{Cd}, \mathrm{Cr}$ and $\mathrm{Pb}$ had lower values than the detection limit. The highest $\mathrm{Cu}$ and Fe contents were in the
Oxisol with 0.68 and $5.04 \mathrm{mg} \mathrm{dm}^{-3}$, respectively. In the Ultisol, the highest found contents were of zinc and manganese, respectively with 16.4 and $463.4 \mathrm{mg} \mathrm{dm}^{-3}$.

From the available metal ions, $\mathrm{Zn}$ and $\mathrm{Mn}$ had correlations among themselves, while $\mathrm{Cu}$ correlated with clay. The variables $\mathrm{CEC}, \mathrm{pH}, \mathrm{Mg}, \mathrm{Ca}$, and $\mathrm{SB}$, as well as $\mathrm{OC}, \mathrm{K}, \mathrm{Mn}$ and $\mathrm{Zn}$ all presented high correlations between themselves, evidenced by the principal components analysis.

\section{Acknowledgements}

To the Federal University of Technology - Paraná, Medianeira Campus, and to the Coordination for the Improvement of Higher Education Personnel (CAPES) for the financial grant to the first author (Financing Code 001).

\section{Literature Cited}

Althaus, D.; Gianello, C.; Tedesco, M.J.; Silva, K.J. Bissani, C.A.; Felisberto, R. Natural fertility and metals contents in soils of Rio Grande do Sul (Brazil). Revista Brasileira de Ciência do Solo, v.42, e0160418, 2018. https://doi.org/10.1590/18069657rb cs20160418

Andrade, M.G.; Melo, V.F.; Souza, L.C.P.; Gabardo, J.; Reissmann, C.B. Metais pesados em solos de área de mineração e metalurgia de chumbo. II - formas e disponibilidade para plantas. Revista Brasileira de Ciência do Solo, v.33, n.6, p.1889-1897, 2009. https://doi.org/10.1590/S0100-06832009000600038.

Biondi, C. M.; Nascimento, C. W. A.; Fabricio Neta, A. B.; Ribeiro, M. R. Teores de Fe, Mn, Zn, Ni e Co em solos de referência de Pernambuco. Revista Brasileira de Ciência do Solo, v.35, n.3, p. 1057-1066, 2011. https://doi.org/10.1590/S010006832011000300039.

Bocardi, J. M. B. Valores de referência de qualidade de metais, macroelementos e radionuclídeos em solos do oeste do Paraná. Guarapuava: Universidade Estadual do Centro-Oeste, 2019. 106p. Tese Doutorado. http://repositorio.utfpr.edu.br/jspui/ handle/1/4691. 29 Mar. 2019.

Bocardi, J. M. B.; Pletsch, A. L.; Rocha, A. S.; Quinaia, S. P. Parâmetros físicos e químicos em solos de unidades de conservação florestal da bacia do Paraná 3, Brasil. Revista Brasileira de Geografia Física, v. 11, n. 1, p. 99-113, 2018. https://periodicos.ufpe.br/revistas/ rbgfe/article/view/234211/pdf. 11 Dez. 2018.

Brasil. Conselho Nacional do Meio Ambiente - CONAMA. Resolução n. 420, de 28 de dezembro de 2009. Dispõe sobre critérios e valores orientadores de qualidade do solo quanto à presença de substâncias químicas e estabelece diretrizes para o gerenciamento ambiental de áreas contaminadas por essas substâncias em decorrência de atividades antrópicas. Diário Oficial da União, v.146, n.249, seção 1, p.81-84, 2009. http:// www.mma.gov.br/port/conama/legiabre.cfm?codlegi=620. 18 Dez. 2018.

Burak, D.L. Geoquímica e distribuição de metais pesados em solos na Região de Unaí, Paracatu e Vazante, MG. Viçosa: Universidade Federal de Viçosa, 2008. 173p. Tese Doutorado. http://locus.ufv. br/handle/123456789/1587. 08 Out. 2018. 
Caires, S.M. Determinação dos teores naturais de metais pesados em solos do estado de Minas Gerais como subsídio ao estabelecimento de valores de referência de qualidade. Viçosa: Universidade Federal de Viçosa, 2009. 304p. Tese Doutorado. http://locus.ufv.br/handle/123456789/1600. 05 Out. 2018.

Campos, M.C.C. Atributos dos solos e riscos de lixiviação de metais pesados em solos tropicais. Ambiência, v.6, n.3, p.547-565, 2010. https://revistas.unicentro.br/index.php/ambiencia/article/ view/591/1154. 02 Dez. 2018

Cassol, C.J.; Cortivo, N.S.D.; Pletsch, A.L.; Costa Júnior, I.L.; Gomes, F.A.L. Determinação de manganês disponível em solos de referência da Mesorregião Oeste do Paraná. Realização, v. 5, n. 9, p. 21-27, 2018. http://ojs.ufgd.edu.br/index.php/realizacao/ article/view/8535/4667. 07 Dez. 2018.

Comissão de Química e Fertilidade do Solo - CQFS-RS/SC. Manual de calagem e adubação para os Estados do Rio Grande do Sul e de Santa Catarina. 11.ed. Porto Alegre: Sociedade Brasileira de Ciência do Solo; Núcleo Regional Sul, 2016. 376p.

Cordovil, M.C.O.; Mendonça, A.G.R.; Botero, W.G.; Santos, A.; Rocha, J.C.; Mello, K.; Toppa, R.H.; Oliveira, L.C. Análise espacial e quimiométrica da distribuição de espécies metálicas em solos alagáveis e não alagáveis da Bacia do Médio Rio Negro, Amazônia. Quím. Nova, v.37, n.5, p.770-775, 2014. https://doi. org/10.5935/0100-4042.20140124.

Coringa, E.A.O.; Couto, E.G.; Perez, X.L.O.; Torrado, P. V. Atributos de solos hidromórficos no Pantanal Norte Matogrossense. Acta Amazonica. v.42, n.1, p.19-28, 2012. https://doi.org/10.1590/ S0044-59672012000100003.

Empresa Brasileira de Pesquisa Agropecuária - Embrapa. Manual de métodos de análise de solo. 2.ed. Rio de Janeiro: Embrapa, 1997. 212p. https://www.agencia.cnptia.embrapa.br/Repositorio/Man ual+de+Metodos_000fzvhotqk02wx5ok0q43a0ram31wtr.pdf. 23 Fev. 2019.

Empresa Brasileira de Pesquisa Agropecuária - Embrapa. Sistema brasileiro de classificação de solos. 3.ed. Brasília: Embrapa, 2013. $353 p$.

Food and Agriculture Organization - FAO. Ano internacional dos solos - 2015. FAO destaca ligação entre solos saudáveis e desenvolvimento sustentável https://news.un.org/pt/tags/anointernacional-dos-solos. 25 Fev. 2019.

Freitas, L.; Casagrande, J.C.; Oliveira, I.A.; Júnior, P.R.S.; Campos, M. C. C. Análises multivariadas de atributos químicos do solo para caracterização de ambientes. Revista Agro@mbiente On-line, v. 8 , n. 2, p. $155-164$, 2014. https://doi.org/10.18227/19828470ragro.v8i2.1684.

Guevara, Y.Z.C.; Souza, J.J.L.L.; Veloso, G.V.; Veloso, R.W.; Rocha, P.A.; Abrahão, W. A. P.; Filho, E. I. F. Reference values of soil quality for the Rio Doce basin. Revista Brasileira de Ciência do Solo, v.42, e0170231, 2018. https://doi.org/10.1590/18069657rb cs20170231.

Guimarães, S.T.; Lima, H.N.; Teixeira, W.G.; Neves Junior, A.F.; Silva, F.W.R.; Macedo, R.S.; Souza, K.W. Caracterização e classificação de Gleissolos da várzea do Rio Solimões (Maracapuru e Iranduba), Amazonas, Brasil. Revista Brasileira de Ciência do Solo, v.37, n.2, p.317-326, 2013. https://doi.org/10.1590/S010006832013000200003.
Hongyu, K.; Sandanielo, V.L.M.; Junior, G.J.O. Análise de componentes principais: resumo teórico, aplicação e interpretação. E\&S Engineering and Science, v.5, n.1, p.83-90, 2016. https://doi. org/10.18607/ES201653398.

Hugen, C.; Miquelluti, D. J.; Campos, M.L.; Lmeida, J.A.; Ferreira, É.R.N.C.; Pozzan, M. Teores de Cu e Zn em Perfis de Solos de Diferentes Litologias em Santa Catarina. Revista Brasileira de Engenharia Agrícola e Ambiental, v.17, n.6, p.622-628, 2013. https://doi.org/10.1590/S1415-43662013000600008.

Instituto de Terras, Cartografia e Geologia do Paraná - ITCG. Mapas geológicos para download. http://www.mineropar.pr.gov.br/ modules/conteudo/conteudo.php?conteudo=154. 02 Fev. 2019.

Kabata-Pendias A. Trace elements in soils and plants. 4.ed. Boca Raton: CRC Press, 2011. 548p.

Kyziol, J. Twardowska, I.; Schmitt-Kopplin, P. The role of humic substances in chromium sorption onto natural organic matter (peat). Chemosphere, v.63, n.11, p.1974-1982, 2006. https://doi. org/10.1016/j.chemosphere.2005.09.042.

Melo, É.E.C.; Nascimento, C.W.A.; Santos, A.C.Q.; Silva, A.S. Disponibilidade e fracionamento de $\mathrm{Cd}, \mathrm{Pb}$, $\mathrm{Cu}$ e $\mathrm{Zn}$ em função do $\mathrm{pH}$ e tempo de incubação com o solo. Ciência e Agrotecnologia, v. 32, n.3, p. 776-784, 2008. https://doi.org/10.1590/S1413-70542008000300011.

Oliveira, L.F.C.; Castro, M.L.L.; Rodrigues, C.; Borges, J.D. Isotermas de sorção de metais pesados em solos do cerrado de Goiás. Revista Brasileira de Engenharia Agrícola e Ambiental, v. 14, n.7, p. 776782, 2010. https://doi.org/10.1590/S1415-43662010000700014.

Paye, H.S.; Mello, J.W.C.V.; Abrahão, W.A.P.; Fernandes Filho, E.I. Dias, L.C.P.; Castro, M.L.O.; Melo, S.B.; França, M.M. Valores de referência de qualidade para metais pesados em solosno Estado do Espírito Santo. Revista Brasileira de Ciência do Solo, v. 34, n. 6, p. 20412051, 2010. https://doi.org/10.1590/S0100-06832010000600028.

Ribas, C. Caracterização da fertilidade atual dos solos de GuarapuavaPR. Guarapuava: Universidade Estadual do Centro-Oeste, 2010. 52p. Dissertação Mestrado. http://unicentroagronomia.com/ destino_arquivo/1_dissert._final_cilton_ribas.pdf. 23 Jan. 2019.

Santos, G.C.G.; Rodella, A.A. Efeito da adição de fontes de matéria orgânica como amenizantes do efeito tóxico de $\mathrm{B}, \mathrm{Zn}, \mathrm{Cu}, \mathrm{Mn}$ e $\mathrm{Pb}$ no cultivo de Brassica juncea. Revista Brasileira de Ciência do Solo, v. 31, n.4, p.793804, 2007. https://doi.org/10.1590/S0100-06832007000400019.

Santos, J.C.B.; Júnior, V.S.S.; Corrêa, M.M.; Ribeiro, M.R.; Almeida, M.C.; Borges, L. E.P. Caracterização de neossolos regolíticos da região semiárida do Estado de Pernambuco. Revista Brasileira de Ciência do Solo, v.36, n.3, p.683-696, 2012. https://doi. org/10.1590/S0100-06832012000300001.

Santos, S.N., Alleoni, L.R.F. Reference values for heavy metals in soils of the Brazilian agricultural frontier in Southwestern Amazônia. Environmental Monitoring and Assessment, v.185, p.5737-5748, 2013. https://doi.org/10.1007/s10661-012-2980-7.

Souza, J.J.L.L.; Fontes, M.P.F.; Gilkes, R.; Costa, L.M.; Oliveira, T.S. Geochemical Signature of Amazon Tropical Rainforest Soils. Revista Brasileira de Ciência do Solo, v.42, e0170192, 2018. http://doi.org/10.1590/18069657rbcs20170192.

Tedesco, M.J.; Gianello, C.; Bissani, C.A.; Bohnen, H. Volkweiss, S.J. Análise de solo, plantas e outros materiais. 2.ed. Porto Alegre: Universidade Federal do Rio Grande do Sul, 1995. 174p. (Boletim Técnico de Solos, 5). https://pt.scribd.com/doc/41082320/ Tedesco-et-al-1995. 05 Nov. 2019. 